\title{
Metode Ekstraksi dan Pemisahan Optimum Untuk Isolasi Xantorizol dari Temulawak (Curcuma xanthorrhiza)
}

\author{
Penulis \\ Wulan Tri Wahyuni ${ }^{1,2,}{ }^{*}$, Herdiyanto ${ }^{1}$, Mohamad Rafi ${ }^{1,2}$ \\ Afiliasi

\footnotetext{
${ }^{1}$ Departemen Kimia, Fakultas Matematika dan Ilmu Pengetahuan Alam, Institut Pertanian Bogor

${ }^{2}$ Pusat Studi Biofarmaka Tropika, Lembaga Penelitian dan Pengabdian Kepada Masyarakat, Institut Pertanian Bogor
}

\section{Kata Kunci \\ C C. Xanthorrhiza \\ O Isolasi \\ O Kromatografi \\ ○ Xantorizol}

Diterima 23 Februari 2017

Direvisi 5 April 2017

Disetujui 10 Juli 2017

*Penulis korespondensi Wulan Tri Wahyuni Departemen Kimia, FMIPA, Institut Pertanian Bogor JI Tanjung Kampus IPB Dramaga, Bogor 16880 Indonesia Email : wulantriws@apps.ipb.ac.id

\section{ABSTRAK}

Xantorizol merupakan senyawa penciri utama temulawak (Curcuma xanthorrhiza). Penelitian ini bertujuan menentukan metode ekstraksi dan pemisahan optimum untuk isolasi xantorizol dari rimpang temulawak. Maserasi dan sokletasi digunakan untuk mengekstraksi xantorizol dengan pelarut metanol, dietil eter, dan $n$-heksana. Pemisahan dilakukan dengan kromatografi kolom dan kromatografi lapis tipis (KLT) preparatif dan hasil pemisahan dikarakterisasi berdasarkan spektrum inframerah dan kromatografi gas-spektrum massa (KG-SM), sementara persentase kemurniannya ditentukan dengan kromatografi cair kinerja tinggi. Ekstrak $n$-heksana dari teknik maserasi memiliki kandungan xantorizol lebih tinggi dibanding ekstrak lainnya yaitu sebesar $168 \mathrm{mg} / \mathrm{g}$ sampel. Fraksi ke-4 hasil pemisahan kolom terhadap ekstrak $n$ heksana memberikan dua spot pada KLT dengan $R_{f} 0.54$ dan 0.68 , spot dengan $\mathrm{Rf} 0.54$ diduga merupakan xantorizol (dikonfirmasi dengan KG-SM). Pemurnian lebih lanjut dengan KLT preparatif terhadap fraksi ke-4 menghasilkan xantorizol dengan rendemen sebesar $0.016 \%$ berdasar bobot sampel dan tingkat kemurnian sebesar $87.40 \%$.

\section{PENDAHULUAN}

Temulawak merupakan tanaman asli Indonesia yang termasuk ke dalam famili Zingiberaceae. Tanaman ini secara empiris dilaporkan dapat mengobati berbagai penyakit seperti radang dan pembengkakan saluran cerna, batu empedu, liver, dyspepsia, antispasmodic (EMA 2014). Secara saintifik temulawak dilaporkan memiliki aktivitas antibakteri, antioksidan, antitumor, antiinflamasi, antijamur, dan hepatoprotektif (Masuda et al. 1992; Lin et al. 1996; Hwang et al. 2000; Hwang 2004; Park et al. 2008). Bagian tanaman temulawak yang digunakan ialah rimpang. Rimpang temulawak merupakan komoditas tanaman obat yang paling banyak digunakan sebagai bahan baku jamu di Indonesia. Rimpang temulawak, terutama dalam bentuk simplisia, juga diekspor ke berbagai negara seperti Singapura, Jerman, dan Taiwan (Syukur dan Hernani 2002). 
Kualitas rimpang temulawak sebagai bahan baku obat tradisional sangat ditentukan oleh senyawa fitokimia yang dikandungnya. Xantorizol (Gambar 1) merupakan senyawa fitokimia khas dalam temulawak, kadar senyawa ini digunakan sebagai penentu kualitas rimpang temulawak. Xantorizol merupakan senyawa golongan seskuiterpena teroksidasi yang memiliki rumus molekul $\mathrm{C}_{15} \mathrm{H}_{22} \mathrm{O}$ dengan bobot molekul sebesar $218.3 \mathrm{~g} / \mathrm{mol}$. Senyawa dengan nama IUPAC 5-(1,5dimetilheks-4-enil)-2-metilfenol ini mempunyai ciri tidak berwarna, stabil terhadap panas, sangat pahit serta larut baik dalam dimetil sulfoksida (DMSO) dan etanol 96\% (Hwang et al. 2000). Xantorizol mempunyai kemampuan sebagai antibakteri (Rukayadi dan Hwang 2007), antijamur (Rukayadi et al. 2006), antikanker (Cheah et al. 2009), antioksidan, dan antiinflamasi (Lim et al. 2005), serta berpotensi untuk penanganan penyakit flu burung (Darusman et al. 2007).

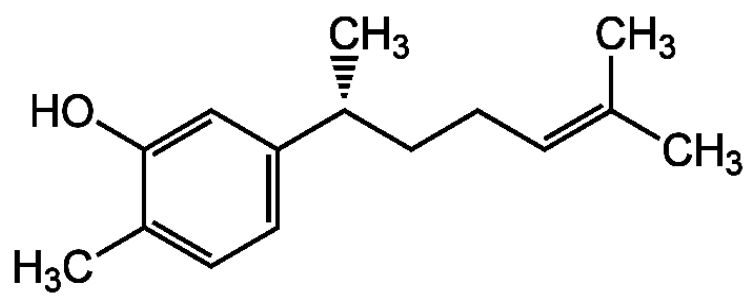

Gambar 1 Struktur xantorizol

Xantorizol dapat diisolasi dari rimpang temulawak dengan beragam metode. Hwang et al. (2000) mengisolasi xantorizol dari temulawak dengan menggunakan metanol $75 \%$ sebagai pengekstrak, dilanjutkan dengan kromatografi kolom serta proses asetilasi dan deasetilasi. Rendemen yang diperoleh sebesar $0.064 \%$ dengan kemurnian $99.90 \%$. Asriani (2010) melakukan modifikasi terhadap metode Hwang dengan mengganti pelarut ekstraksi menggunakan etanol $96 \%$ dan tanpa tahapan kromatografi kolom. Asriani melakukan pemurnian xantorizol menggunakan KLT peparatif dan menghasilkan rendemen sebesar $0.140 \%$ serta kemurniannya $99.50 \%$.

Kebutuhan terhadap xantorizol sebagai senyawa penanda untuk kontrol kualitas temulawak tidak diiringi dengan ketersediaan xantorizol dalam jumlah memadai di pasaran. Perlu dilakukan pengoptimuman metode isolasi xantorizol dari temulawak untuk mendapatkan rendemen yang lebih besar dan kemurnian tinggi. Dalam penelitian ini dilakukan pengoptimuman metode ekstraksi dan pemisahan xantorizol dari rimpang temulawak. Teknik ekstraksi maserasi digunakan karena merupakan teknik ekstraksi yang sederhana, sementara sokletasi dipilih karena merupakan teknik ekstraksi sinambung yang diharapkan dapat meningkatkan rendemen ekstraksi xantorizol. Tahap pemurnian yang digunakan meliputi kromatografi kolom dan kromatografi lapis tipis preparatif dengan tujuan meningkatkan kemurnian xantorizol yang diperoleh. Berbeda dari metode yang telah dikembangkan oleh Hwang et al. (2000) dan Asriani (2010), pada penelitian ini tidak dilakukan proses asetilasi dan deasetilasi selama pemurnian dengan tujuan untuk meminimalkan waktu isolasi.

\section{METODE}

\section{Alat dan Bahan}

Peralatan yang digunakan dalam penelitian ini yaitu evaporator putar WB 2000 (Heidolph, Jerman), spektrofotometer UV-Vis U-2000 (Hitachi, Jepang), spektrofotometer FTIR Tensor 37 (Bruker, Jerman), kromatografi cair kinerja tinggi (KCKT) tipe LC-20A (Shimadzu, Jepang), kromatografi gas-spektrometri massa (KG-SM) tipe GC 6890 MS 5973 (Agilent, Jerman), dan alat-alat kaca yang umum digunakan dalam laboratorium kimia.

Bahan-bahan yang digunakan adalah simplisia rimpang temulawak (Unit Konservasi dan Budidaya Biofarmaka, Pusat Studi Biofarmaka Tropika, Lembaga Penelitian dan Pengabdian kepada Masyarakat Institut Pertanian Bogor (LPPM IPB), Standar xantorizol (donasi Prof JK Hwang, Yonsei University, Korea Selatan), Kromatografi Lapis Tipis (KLT) analitik silika gel $60 \mathrm{~F}_{254}$ (Merck, Jerman), dan KLT preparatif silika gel $60 \mathrm{~F}_{254}$ (Merck, Jerman), metanol, dietil eter, $n$-heksana, etil asetat, dan silika gel (Merck, Jerman).

\section{Determinasi Tanaman}

Temulawak yang digunakan diidentifikasi di Balai Penelitian dan Pengembangan Botani (Herbarium Bogoriense), Pusat Penelitian dan Pengembangan Biologi-Lembaga Ilmu Pengetahuan Indonesia (LIPI) Cibinong, Bogor, Jawa Barat. Voucher spesimen temulawak yang digunakan dalam penelitian disimpan dengan nomor seri spesimen BMK0042071014 asal Unit Konservasi dan Budidaya Biofarmaka-Pusat Studi Biofarmaka Tropika LPPM IPB.

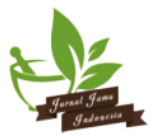




\section{Ekstraksi simplisia rimpang temulawak}

Sebanyak 300 gram serbuk simplisia kering rimpang temulawak diekstraksi dengan cara maserasi menggunakan metanol, dietil eter, dan $n$-heksana (1:5 b/v). Maserasi dilakukan selama $3 \times 24$ jam untuk masing-masing pelarut dengan penggantian pelarut setiap 24 jam. Maserat dari proses ekstraksi dengan masing-masing pelarut kemudian diuapkan dengan penguap putar. Ekstrak pekat yang diperoleh kemudian dianalisis kandungan xantorizolnya menggunakan KCKT. Selain dengan metode maserasi, ekstraksi juga dilakukan dengan metode sokletasi. Proses sokletasi dilakukan selama 6 jam, sementara pelarut ekstraksi dan nisbah bahan:pelarut yang digunakan sama dengan pada ekstraksi maserasi. Ekstrak yang diperoleh dipekatkan dan kadar xantorizol dalam ekstrak pekat ditentukan dengan KCKT.

\section{Penentuan kadar xantorizol dengan metode KCKT}

Kadar xantorizol ditentukan menggunakan KCKT dengan kondisi KCKT yang digunakan ialah sebagai berikut: kolom $\mathrm{C} 18$, detektor UV-Vis, volume injeksi 10 $\mu \mathrm{L}$, elusi isokratik (eluen $\mathrm{H}_{3} \mathrm{PO}_{4}$ dan metanol) serta suhu kolom $40{ }^{\circ} \mathrm{C}$ (Darusman et al. 2007).

Pemisahan xantorizol pada ekstrak rimpang temulawak dengan kromatografi kolom dan lapis tipis preparatif

Ekstrak temulawak dengan kadar xantorizol tertinggi selanjutnya dipisahkan dengan kromatografi kolom dilanjutkan kromatografi lapis tipis (KLT) preparatif. Pemisahan dengan kromatografi kolom dilakukan dengan fase diam berupa silika gel dan fase gerak berupa campuran $n$-heksana:etil asetat (ditentukan berdasarkan penentuan eluen terbaik dengan KLT analitik, tidak dilaporkan dalam tulisan ini). Fraksi-fraksi yang diperoleh dari pemisahan kromatografi kolom dievaluasi pada KLT analitik, spot yang terbentuk dibandingkan dengan spot standar xantorizol. Fraksi terpilih difraksinasi lebih lanjut dengan KLT preparatif. Spot dengan $R_{f}$ yang sama dengan standar xantorizol dikeruk, dilarutkan dalam $n$-heksana, selanjutnya dipekatkan.

\section{Identifikasi Fraksi KLTP Terpilih (Isolat Xantorizol) Spektrum FTIR}

Sebanyak $\pm 2 \mathrm{mg}$ isolat xantorizol hasil fraksionasi dicampurkan dengan $\mathrm{KBr}$. Campuran tersebut dibentuk pellet dengan bantuan hand press Shimadzu pada tekanan $8 \mathrm{kN}$ selama 15 menit. Pelet sampel dianalisis dengan FTIR pada daerah $4000-400 \mathrm{~cm}^{-1}$ dengan jumlah payar $32 /$ menit dan resolusi $4 \mathrm{~cm}^{-1}$.

\section{Analisis isolat xantorizol dengan KG-SM}

Isolat yang didapat dari hasil fraksionasi menggunakan KLT preparatif kemudian dianalisis menggunakan KG-SM dengan kondisi sebagai berikut: kolom HP-5 MS, dimensi $60 \mathrm{~m} \times 250 \mu \mathrm{m}$. Suhu terprogram dari $70{ }^{\circ} \mathrm{C}$ sampai $290{ }^{\circ} \mathrm{C}$ (selama 40 menit) dengan kenaikan suhu sebesar $15{ }^{\circ} \mathrm{C} /$ menit. Suhu injektor $290{ }^{\circ} \mathrm{C}$. Suhu detektor $250{ }^{\circ} \mathrm{C}$. Mode injeksi split (50:1) dan tekanan inlet sebesar 18.03 psi. Gas pembawa berupa helium dengan laju alir $1 \mathrm{~mL} /$ menit. Spektrometer massa yang digunakan dengan energi ionisasi $70 \mathrm{eV}$, mode ionisasi tumbukan elektron. Area deteksinya ialah $40-800 \mathrm{~m} / \mathrm{z}$. Setiap puncak yang muncul dalam kromatogram ion total diidentifikasi dengan menganalisis hasil spektrum massa yang terdapat pada pustaka spektrometer massa.

\section{Evaluasi kemurnian isolat xantorizol}

Kemurnian isolat xantorizol ditentukan berdasarkan rasio area puncak xantorizol terhadap area seluruh puncak yang terdeteksi pada kromatogram KCKT. Analisis KCKT dilakukan dengan metode yang sama seperti pada penentuan kadar xantorizol.

\section{HASIL DAN PEMBAHASAN}

\section{Ekstrak Rimpang Temulawak dan Kadar Xantorizol dalam Ekstrak}

Rendemen ekstraksi rimpang temulawak ditunjukkan pada Tabel 1. Pelarut $n$-heksana secara konsisten memberikan rendemen ekstraksi tertinggi baik pada ekstraksi dengan metode maserasi maupun sokletasi. Di antara ketiga pelarut yang digunakan, $n$ heksana merupakan pelarut dengan polaritas terendah (indeks polaritas, $P=0.1$ ) dibandingkan dietil eter $(P=$ 2.8) dan metanol $(P=5.1)$. Pelarut $n$-heksana terkategori sebagai pelarut nonpolar. Hasil ini mengindikasikan bahwa senyawa metabolit sekunder yang terdapat pada rimpang temulawak mayoritas larut dalam pelarut yang bersifat nonpolar. Rimpang temulawak banyak mengandung minyak atsiri yang terdiri atas senyawa golongan seskuiterpena yang larut dalam pelarut non-polar seperti $n$-heksana (Zwaving dan Bos 1992; Jarikasem et al. 2005).

Sementara itu, rendemen ekstraksi metode sokletasi dengan tiga pelarut yang digunakan selalu lebih tinggi

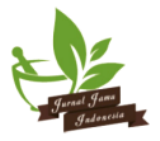


Tabel 1 Rendemen ekstrak temulawak dan kadar xantorizol dalam ekstrak temulawak

\begin{tabular}{ccccc}
\hline \multirow{2}{*}{ Pelarut } & \multicolumn{2}{c}{ Rendemen (\%) } & \multicolumn{2}{c}{ Kadar xantorizol (mg/g) } \\
& Maserasi & Sokletasi & Maserasi & Sokletasi \\
\hline Metanol & 5.45 & 12.73 & 61.57 & 61.96 \\
Dietil eter & 4.98 & 6.65 & 78.30 & 78.48 \\
n-heksana & 12.47 & 17.19 & 168.12 & 163.35 \\
\hline
\end{tabular}

dibandingkan rendemen metode maserasi. Ekstraksi dengan metode sokletasi dilakukan dengan menggunakan bantuan pemanasan sehingga interaksi pelarut dengan bahan terjadi lebih optimal. Penggunaan panas pada metode ekstraksi sokletasi menyebabkan energi kinetik pelarut meningkat sehingga berinteraksi lebih intensif dengan bahan. Hal ini menyebabkan komponen yang terdapat dalam sampel lebih efektif terekstrak ke dalam pelarut. Di samping itu, pada teknik sokletasi ekstraksi selalu dilakukan oleh pelarut yang segar, sementara pada maserasi pelarut telah jenuh dengan ekstrak.

Kandungan xantorizol dalam ekstrak $n$-heksana jauh lebih tinggi dibandingkan dalam ekstrak metanol dan dietil eter. Salea et al. (2014) membandingkan efektivitas ekstraksi xantorizol dengan pelarut $n$ heksana dan fluida superkritis $\mathrm{CO}_{2}$ dan memperoleh informasi bahwa rendemen ekstraksi dengan fluida superkritis $\mathrm{CO}_{2}$ memberikan rendemen lebih tinggi. Namun demikian, ekstraksi dengan $n$-heksana dapat menjadi alternatif metode ekstraksi xantorizol.

Analisis kadar xantorizol dalam ekstrak rimpang temulawak dilakukan dengan KCKT fase terbalik menggunakan $\mathrm{C} 18$ sebagai fase diam dan campuran $\mathrm{H}_{3} \mathrm{PO}_{4}$ dengan metanol sebagai fase gerak. Puncak senyawa xantorizol standar maupun xantorizol dalam ekstrak rimpang temulawak muncul pada waktu retensi sekitar 16 menit (data tidak ditunjukkan). Penentuan xantorizol dengan standardisasi satu titik menunjukkan bahwa ekstrak heksana mengandung xantorizol dengan kadar hampir tiga kali lebih tinggi dibandingkan ekstrak metanol dan dietil eter (Tabel 1). Jenis pelarut teramati memengaruhi rendemen xantorizol yang terekstrak dari rimpang temulawak, sementara pengaruh metode ekstraksi terhadap kadar xantorizol yang terekstrak tidak signifikan. Hasil yang diperoleh menunjukkan kadar xantorizol pada ekstrak hasil ekstraksi maserasi dengan pelarut $n$-heksana sedikit lebih tinggi dari ekstrak hasil sokletasi.

\section{Fraksi Xantorizol Hasil Pemisahan Kromatografi Kolom dan Lapis Tipis Preparatif}

Eluen untuk pemisahan ekstrak temulawak dengan kromatografi kolom diperoleh melalui pengoptimuman fase gerak dengan KLT analitik. Fase gerak terpilih ialah $n$-heksana:etil asetat dengan perbandingan 10:1. Berdasarkan hasil pemisahan menggunakan KLT, spot dengan Rf 0.55 diduga merupakan xantorizol, spot menunjukkan warna keunguan setelah diberi pereaksi penampak noda vanillin (Gambar 2). Spot dugaan xantorizol ini kemudian dipisahkan dari sampel menggunakan kromatografi kolom.

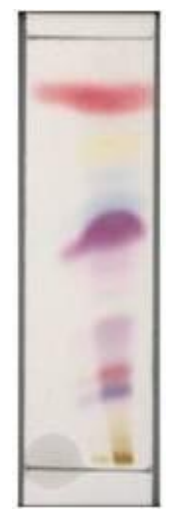

Gambar 2 Kromatogram KLT ekstrak n-heksana metode maserasi dengan eluen $n$-heksanaetil asetat (10:1) setelah diberi pereaksi penampak noda vanillin

Sebanyak 5.0079 gram sampel $n$-heksana hasil maserasi difraksionasi dengan kromatografi kolom menggunakan elusi isokratik. Sampel dielusi dengan $500 \mathrm{~mL} n$-heksana sebagai awal kemudian dielusi menggunakan eluen terbaik hingga spot dugaan xantorizol selesai dielusi. Pengelompokkan fraksi hasil kromatografi kolom dilakukan dengan bantuan lampu UV $254 \mathrm{~nm}$ dan penyemprotan dengan pereaksi vanilin. Diperoleh 6 fraksi hasil kromatografi kolom, fraksi ke-4 (rendemen $17.85 \%$ ) merupakan fraksi yang diduga mengandung xantorizol. Fraksi ke-4 ini menghasilkan 2

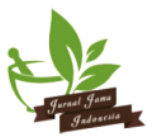


spot pada pemisahan dengan KanLT analitik, yaitu pada $\mathrm{R}_{\mathrm{f}} 0.54$ (diduga sebagai spot xantorizol) dan $\mathrm{Rf} 0.68$.

Fraksi ke-4 kemudian difraksionasi lebih lanjut dengan KLT preparatif untuk mendapatkan senyawa tunggal berupa xantorizol dari 2 spot yang terdeteksi pada pengujian sebelumnya. Pemisahan 0.5008 gram fraksi ke- 4 menghasilkan spot dengan $R_{f} 0.54$ (diduga sebagai isolat xantorizol) dengan rendemen sebesar $4.78 \%$.

\section{Identitas Fraksi Xantorizol Berdasarkan Spektrum FTIR}

Hasil fraksionasi dikarakterisasi dengan spektroskopi FTIR. Terdapat serapan kuat yang khas pada bilangan gelombang sekitar $3400 \mathrm{~cm}^{-1}$ yang menyatakan keberadaan gugus regang $-\mathrm{OH}$ pada sampel (Gambar 3). Selain itu, terdapat pula serapan pada bilangan gelombang $3000 \mathrm{~cm}^{-1}$ dan $1400 \mathrm{~cm}^{-1}$ yang menyatakan gugus regang aromatik dan regang alkana yang terikat pada aromatik (gugus $-\mathrm{CH}_{3}$ ). Serapan pada daerah $1600 \mathrm{~cm}^{-1}$ menyatakan adanya ikatan alkena (regang $\mathrm{C}=\mathrm{C}$ ) pada rantai karbon dan daerah 1100-1300 $\mathrm{cm}^{-1}$ menyatakan atom $\mathrm{C}$ terikat pada atom $\mathrm{O}$ (Pavia et al. 2008). Berdasarkan gugus fungsi yang teridentifikasi, dapat disimpulkan bahwa sampel merupakan golongan seskuiterpenol yang memiliki gugus benzena terikat $\mathrm{OH}$ yang sesuai dengan struktur xantorizol.

\section{Identitas Fraksi Xantorizol Berdasarkan KG-SM}

Tahap karakterisasi selanjutnya dilakukan menggunakan teknik KG-SM. Kromatogram KG-SM dari isolat xantorizol menunjukkan satu puncak mayor dengan waktu retensi 14.96 menit (Gambar 4a) dengan persentase area sebesar 93.14\%. Bobot molekul dari puncak tersebut (berdasarkan $\mathrm{m} / \mathrm{z}$ yang diperoleh dari spektrum massanya) ialah sebesar $218.2 \mathrm{~g} / \mathrm{mol}$ (Gambar 4b). Berdasarkan kecocokan dengan pangkalan data diperoleh persen kemiripan struktur isolat xantorizol dengan standar xantorizol sebesar 96\%. Selain itu terdeteksi puncak dengan $\mathrm{m} / \mathrm{z} 136$ $\mathrm{g} / \mathrm{mol}$ dengan intensitas tertinggi. Spektrum massa ini memiliki pola fragmentasi yang identik jika dibandingkan dengan spektrum xantorizol yang terdapat pada National Institute Standards and Technology (NIST) (2011) sehingga dapat disimpulkan bahwa senyawa hasil isolasi adalah xantorizol.

Fragmen-fragmen yang terbentuk mencirikan senyawa dengan $\mathrm{m} / \mathrm{z} 218 \mathrm{~g} / \mathrm{mol}$ terbelah pada posisi $\beta$ dari cincin benzena membentuk senyawa dengan $\mathrm{m} / \mathrm{z}$ $136 \mathrm{~g} / \mathrm{mol}$. Senyawa tersebut juga mengalami pembelahan di gugus alkena membentuk ion molekul karbokation dengan $\mathrm{m} / \mathrm{z} 175 \mathrm{~g} / \mathrm{mol}$. Spektum massa juga menunjukkan terdapat serapan kuat pada $\mathrm{m} / \mathrm{z} 91$ $\mathrm{g} / \mathrm{mol}$ dan $53 \mathrm{~g} / \mathrm{mol}$. Fragmen-fragmen ini diduga terbentuk dari senyawa dengan $\mathrm{m} / \mathrm{z} 136 \mathrm{~g} / \mathrm{mol}$ yang

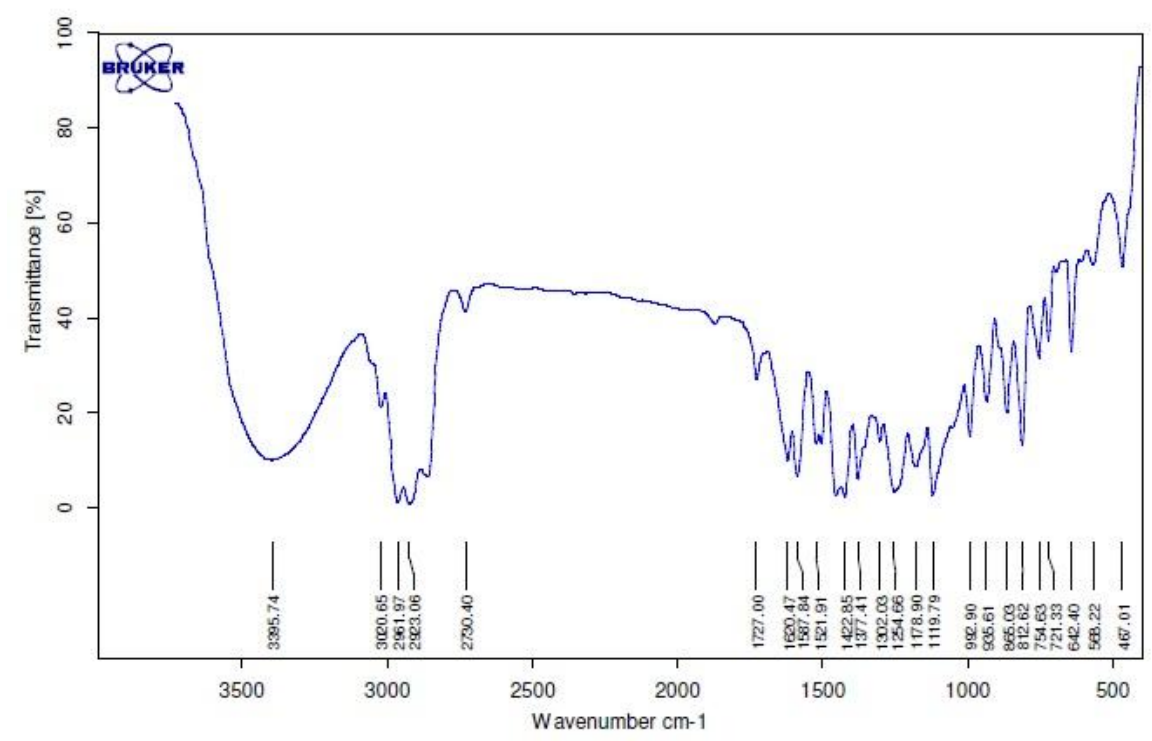

Gambar 3 Spektra FTIR isolat xantorizol hasil pemisahan dengan kromatografi kolom dan KLT preparatif 
Abundance

(a)

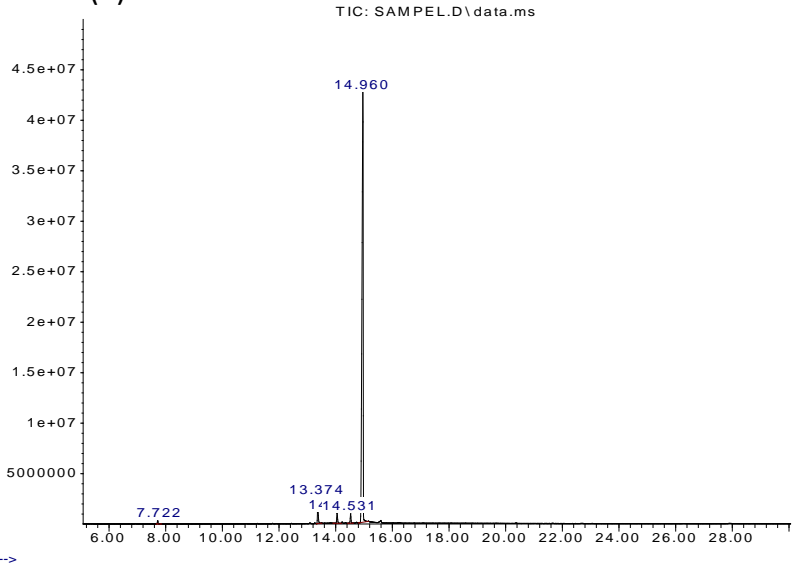

Abundance

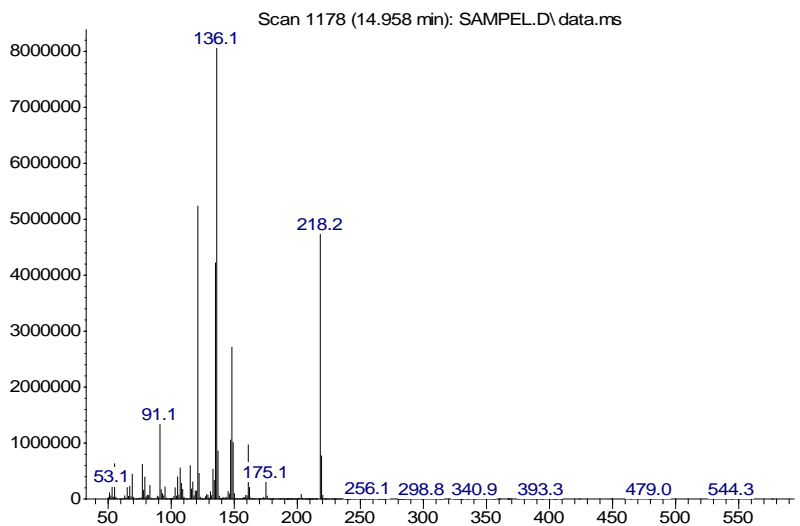
$m / z \rightarrow$

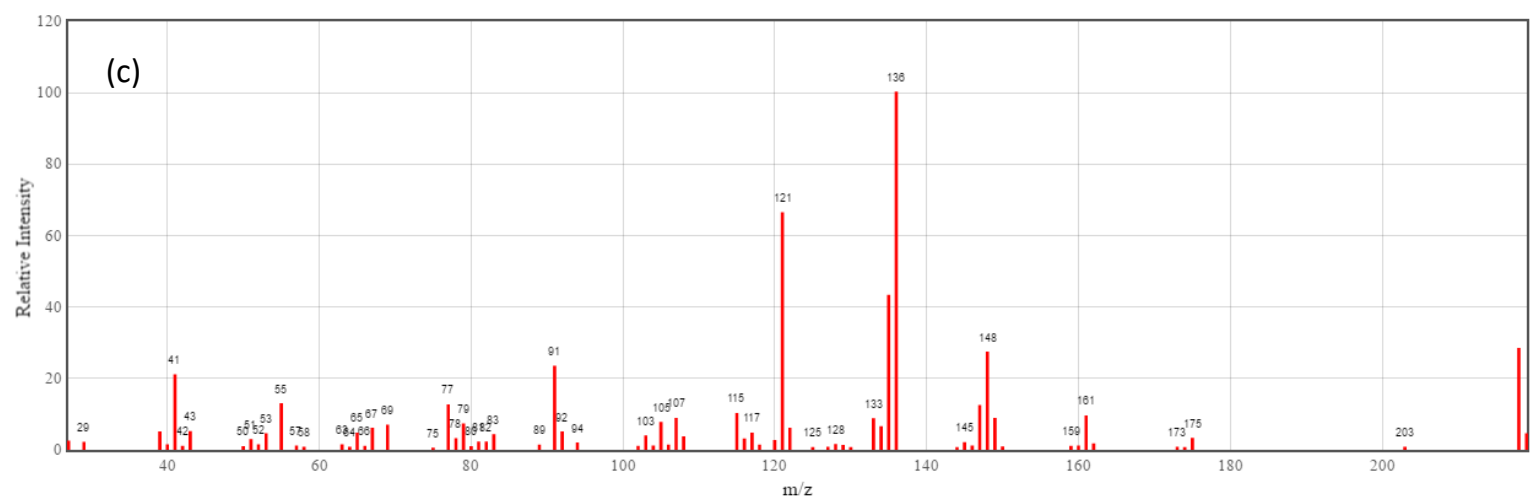

Gambar 4 Kromatogram KG-SM senyawa isolat yang diduga xantorizol (a), spektra massa senyawa isolat yang diduga xantorizol (b), spektra massa standar xantorizol mengacu pada National Institute of Standard and Technology (NIST) (c).

kelimpahannya besar. Senyawa dengan $\mathrm{m} / \mathrm{z} 91$ diduga mengalami pemutusan gugus alkana dan $-\mathrm{OH}$, sedangkan untuk senyawa dengan $\mathrm{m} / \mathrm{z} 53 \mathrm{~g} / \mathrm{mol}$ terbentuk dari ion tropilium sikloheptena dengan $\mathrm{m} / \mathrm{z}$ $105 \mathrm{~g} / \mathrm{mol}$. Prosesnya disebut proses pembentukan ion tropilium dengan pembuangan gugus etena. Ion ini terbentuk dari resonansi hasil pembelahan senyawa dengan $\mathrm{m} / \mathrm{z} 136 \mathrm{~g} / \mathrm{mol}$ melalui pemutusan gugus $-\mathrm{CH}_{3}$ dan -OH (Pavia et al. 2008). Dugaan pola pembelahan selengkapnya ditunjukkan pada Gambar 5.

\section{Kemurnian Xantorizol Hasil Isolasi}

Kemurnian isolat xantorizol ditentukan menggunakan KCKT. Isolat yang diperoleh dari hasil fraksionasi dengan KLT preparatif diukur kembali kadar xantorizolnya. Rendemen akhir diperoleh sebesar $0.016 \%$. Persentase kemurniannya jika dibanding dengan standar xantorizol berdasarkan persen area didapat hasil sebesar $87.40 \%$. Rendemen dan kemurnian xantorizol yang diperoleh masih lebih rendah dibandingkan dengan hasil yang diperoleh oleh Hwang et al. (2000) maupun Asriani (2010) akan tetapi proses isolasi yang diperlukan lebih singkat tanpa dan sederhana, yaitu tanpa tahap asetilasi dan deasetilasi.

\section{KESIMPULAN}

Ekstraksi xantorizol dari rimpang temulawak dengan pelarut $n$-heksana menggunakan metode maserasi memberikan rendemen lebih besar dibandingkan pelarut metanol dan dietil eter. Teknik ekstraksi sokletasi dengan pelarut metanol dan dietil eter memberikan rendemen xantorizol yang sama besar dengan teknik maserasi, kecuali saat digunakan $n$ heksana sebagai pelarut ekstraksi. Pemisahan xantorizol dari ekstrak $n$-heksana menggunakan kromatografi kolom dan KLT preparatif dengan fase diam silika gel dan fase gerak $n$-heksana:etil asetat $(10: 1)$ menghasilkan isolat xantorizol dengan rendemen

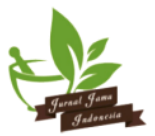




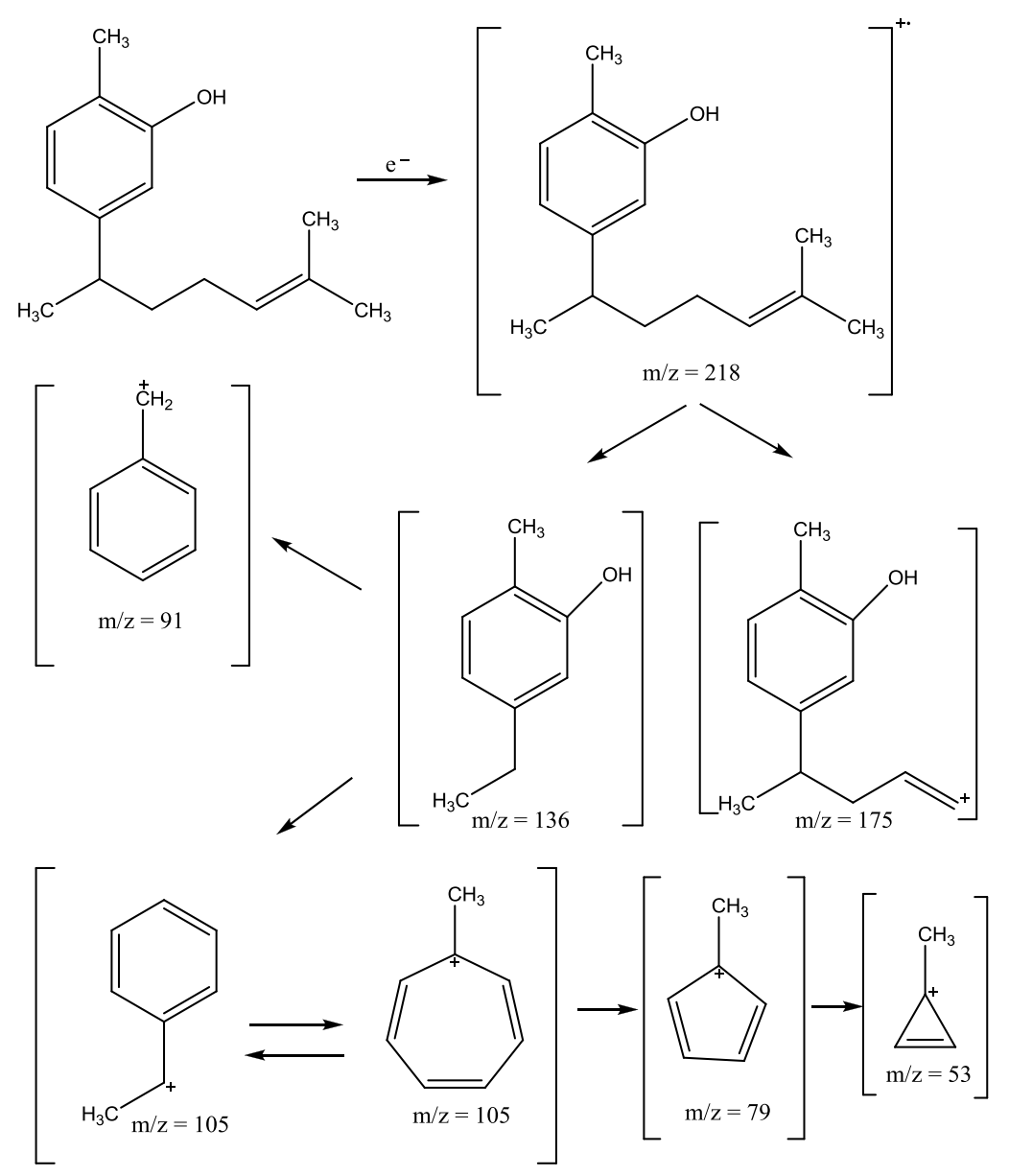

Gambar 5 Dugaan pola fragmentasi xantorizol

sebesar $0.016 \%$ berdasarkan bobot simplisia dan kemurnian sebesar $87.40 \%$. Metode ekstraksi dan pemurnian tanpa tahapan asetilasi dan deasetilasi yang dikembangkan lebih sederhana, namun rendemen dan kemurnian yang diperoleh masih lebih rendah dibandingkan metode yang telah dikembangkan sebelumnya.

\section{DAFTAR PUSTAKA}

Asriani D. 2010. Isolasi xantorizol dari temulawak terpilih berdasarkan nomor harapan. Tesis. Bogor (ID): Fakultas matematika dan Ilmu Pengetahuan Alam, Institut Pertanian Bogor.

Cheah YH, Nordin FJ, Sarip R, Tee TT, Azimahtol HLP, Sirat HM, Rashid BAA,Abdullah NR,Ismail Z. 2009. Combined xanthorrhizol-curcumin exhibits synergistic growth inhibitory activity via apoptosis induction in human breast cancer cells. Cancer Cell International. 9:1 MDA-MB-231.

Darusman LK, Priosoeryanto BP, Hasanah M, Rahardjo M, Purwakusumah ED . 2007. Potensi Temulawak Terstandar untuk Menanggulangi Flu Burung. [Internet] [diunduh 2014 Jan 18]. Tersedia pada: http//repository.ipb.ac.id/bitstream/handle/123 456789/.../2007lkd_latif.doc?..2.

[EMA] European Medicines Agency. 2014. Assessment report on Curcuma xanthorrhiza Roxb. (C. xanthorrhiza D. Dietrich), rhizome. EMA/HMPC/604598/2012.

Hwang JK, Shim JS, Pyun YR. 2000. Antibacterial activity of xanthorrhizol from Curcuma xanthorrhiza against oral pathogens. Fitoterapia. 71:321-323. doi: 10.1016/S0367-326X(99)00170-7

Hwang JK. 2004. Xanthorrhizol: a potential antibacterial agent from Curcuma xanthorrhiza against 
Streptococcus mutans. Planta Medica. 66:196197.

Jarikasem S, Thubthimthed K, Chawananoraseth, Suntorntanasat T. 2005. Essential oil from three Curcuma species collected in Thailand. Acta Horticulturae. 677:37-41.

Lim et al. 2005. Antioxidant and antiinflammatory activities of xanthorrizol in hippocampal neurons and primary cultured microglia. Journal of Neuroscience Research 82 (6):831-8.

Lin SC, Teng CW, Lin CC, Lin YH, Supriyatna S. 1996. Protective and therapeutic effect of the Indonesian medicinal herb Curcuma xanthorrhiza on $\beta$-D-galactosamine-induced liver damage. Phytotherapy Research. 10:131-135.

Masuda T, Isobe J, Jitoe A, Nakatani N. 1992. Antioxidative curcuminoids from rhizomes of Curcuma xanthorrhiza. Phytochemistry. 31:36453647.

[NIST] National Institute Standard Technology. 2011. Material Measurement Laboratory: Phenol, 5(1,5 dimethyl-4-hexenyl)-2-methyl-,(R)-. [Internet] [diunduh 2014 Okt 12]. Tersedia pada: http//webbook.nist.gov/cgi/cbook.cg $i ? I D=C 30199269 \&$ Mask=200.

Park JH, Park KK, Kim MJ, Hwang JK, Lee SK, Chung WY. 2008. Cancer chemoprotective effects of
Curcuma xanthorrhiza. Phytotherapy Research. 22:695-698.

Pavia DL, Gary ML, George SK, James RV. 2008. Introduction to Spectroscopy $4^{\text {th }}$ Edition. Washington: Brooks/Cole CENGAGE Learning. Halaman 27-83.

Rukayadi Y, Yong D, Hwang JK. 2006. In vitro anticandidal activity of xanthorrizol isolated from Curcuma xanthorrhiza Roxb. Antimicrobial Chemotheraphy. Journal of Antimicrobial Chemotherapy. 57:1231-1234.

Rukayadi Y, Hwang JK. 2007. In vitro antimycotic activity of xanthorrhizol isolated from Curcuma xanthorrhiza Roxb. against opportunistic filamentous fungi. Phytotherapy Research. (5):434-438.

Salea R, Widjojokusumo E, Veriansyah B, Tjandrawinata R. 2014. Optimizing oil and xanthorrhizol extraction from Curcuma xanthorrhiza Roxb. rhizome by supercritical carbon dioxide. Journal of Food Science and Technology. 51(9):21972203.

Syukur C, Hernani. 2002. Budi Daya tanaman Obat Komersial. Jakarta (ID): Penebar Swadaya.

Zwaving JH, Bos R. 1992. Analysis of the essential oils of five curcuma species. Flavour and Fragrance Journal. 7(1):19-22. 